\title{
ABSTRAK \\ PENGARUH LAMA PROSES FERMENTASI PADA UBI KAYU (Manihot Esculenta crantz) TERHADAP KADAR ASAM LEMAK
}

\author{
Nur Alim Natsir, Dosen Prodi Pendidikan Biologi IAIN, Ambon \\ 085243549813 E-mail : nuralimnatsir@gmail.com
}

\begin{abstract}
Hasil penelitian menunjukkan bahwa lama proses fermentasi pada ubi kayu dapat mempengaruhi kadar asam lemak yaitu pada selang waktu fermentasi 0 hari ( $\left.\mathrm{P}_{0} / \mathrm{kontrol}\right)$ kadar asam lemak bebasnya $1,22 \%$ dan waktu fermentasi 3 hari $\left(\mathrm{P}_{1}\right)$ kadar asam lemaknya bertambah yaitu 9,82\%. Setelah fermentasi 5 hari $\left(\mathrm{P}_{2}\right)$ kadar asam lemak turun menjadi 8,61\%, dan pada fermentasi 7 hari $\left(\mathrm{P}_{3}\right)$ kadar asam lemak lebih menurun menjadi $5,64 \%$ dan pada fermentasi 9 hari (P4) kadar asam lemak tambah menurun menjadi 5,33\%. Hasil analisis kadar asam lemak tape ubi kayu berpengaruh sangat nyata pada taraf signifikan $1 \%$ dan $5 \%$ dengan $\mathrm{F}_{\text {hitung }}$ sebesar 66,6467 dan $\mathrm{F}_{\text {tabel }} 5 \%=3,48$ dan $\mathrm{F}_{\text {tabel }} 1 \%=5,98$.
\end{abstract}

Kata kunci: fermentasi, ubi kayu, kadar asam lemak

\section{THE INFLUENCE OF LONG FERMENTATION PROCESS IN CASSAVA (Manihot esculenta CRANTZ) AGAINST THE FATTY ACID LEVELS}

The results showed that the long process of fermentation on cassava can affect the levels of fatty acids in fermentation time interval 0 day (P0/controls) the levels of free fatty acids $1.22 \%$ and fermentation time of 3 days (P1) increased levels of fat acids namely 9,82\%. After 5 days of fermentation (P2) fatty acid levels dropped to $8,61 \%$, and in fermentation of 7 days (P3) more fatty acid levels decreased to $5.64 \%$ and fermented at 9 days (P4) added fatty acids levels decreased to 5,33\%. Results of the analysis of the fatty acid levels tape manioc effect is evident in the significant level of $1 \%$ and $5 \%$ with $\mathrm{F}_{\text {count }}$ of 66,6467 and $\mathrm{F}_{\text {table }} 5 \%=3,48$ and $\mathrm{F}_{\text {table }} 1 \%=5.98$.

Keywords: fermentation, manioc, fatty acid levels

Makanan tidak selalu dikonsumsi dan jenis makanan lain. Pengolahan
dalam bentuk seperti bahan mentahnya, bertujuan untuk menambah cita rasa,
tetapi sebagian besar biasanya terlebih bentuk yang diinginkan dengan
dahulu diolah menjadi berbagai bentuk mempertahankan kualitas makanan,


sedangkan pengawetan bertujuan untuk memperpanjang masa simpan bahan pangan tersebut. Bahan mentah hasil panen kalau dibiarkan begitu saja, lamakelamaan akan mengalami perubahan akibat pengaruh-pengaruh fisiologik, mekanik, fisik, kimiawi, parasitik, atau mikrobiologik (Winarno, 1982).

Salah satu sifat bahan-bahan yang paling tidak disukai adalah sifatnya yang mudah busuk. Hal ini disebabkan oleh sifat dari komponen-konponen penyusunnya, terutama pada kadar air yang relatif tinggi. Untuk mengatasi hal tersebut, perlu dilakukan upaya pengolahan dalam bentuk aplikasi teknologi baik konvensional maupun nonkonvensional. Tidak setiap bahan mentah dapat diolah dengan proses yang sama, karena setiap bahan mentah mempunyai karakteristik tersendiri yang sudah barang tentu memerlukan penanganan yang khusus pula. Salah satu jenis tanaman pangan yang sudah lama dikenal dan dibudi dayakan petani di seluruh Wilayah Nusantara adalah ubi kayu (Manihot esculenta crantz). Potensi nilai ekonomi dan sosial ubi kayu merupakan bahan pangan masa depan yang berdaya guna, bahan baku berbagai industri, dan pokok ternak (Rukmana, 1997).

Di Indonesia ubi kayu (singkong) merupakan makanan pokok ketiga setelah beras dan jagung. Negara Indonesia merupakan negara penghasil ubi kayu terbesar kedua di dunia setelah Brazilia. Produksi ubi kayu rata-rata di Indonesia adalah 9,5 juta ton per ha pertahun. Sedangkan produk rata-rata dunia adalah 10,0 juta ton (Astawan, 1988). Di Indonesia dan daerah-daerah tropis lainnya, ubi kayu mempunyai arti ekonomi terpenting di antara jenis umbiubian yang lainnya, sebab selain dapat dikonsumsi langsung umbinya dapat dijadikan tepung tapioka, gaplek, pelet, tape, dekstrin, lem, kerupuk, dan lainlainnya. Tapi ubi kayu sendiri dapat diolah lebih lanjut menjadi alkohol, sirup glukosa, sari tape, sirup fruktosa, asam cuka, tepung tape, dan sebagainya. Dari tepung tape selanjutnya bisa dihasilkan bahan pencampur roti, es krim, aneka kue, dan sebagainya.

Tape murupakan hasil fermentasi alkohol dari ubi kayu. Makanan-makanan produk fermentasi alkohol ini umumnya memiliki cita rasa yang digemari, yaitu rasa asam manis dengan flavour alkohol. 
Fermentasi dapat terjadi karena adanya aktivitas mikroba penyebab fermentasi pada substrat organik yang sesuai. Terjadinya fermentasi ini dapat menyebabkan perubahan sifat pada pangan, sebagai akibat pemecahan dari kandungan-kandungan bahan panga tersebut. Di samping asam, produk (metabolit) hasil fermentasi yang berhubungan dengan pengawetan makanan ialah alkohol. Bila kondisi lingkungan memungkinkan, makananmakanan yang dihasilkan melalui proses fermentasi alkohol akan mengalami fermentasi lebih lanjut dengan menghasilkan produk-produk asam. Terjadinya fermentasi lebih lanjut ini dapat ditandai dengan timbulnya rasa asam pada makanan tersebut.

Fermentasi tape ubi kayu dibagi menjadi dua tahap yaitu: perubahan pati menjadi gula sederhana oleh enzim amilase yang diproduksi oleh kapang dilanjutkan dengan perubahan gula menjadi alkohol oleh khamir, sehingga mempunyai rasa manis dan alkohol sedikit asam. Tape ubi kayu telah populer dikenal oleh masyarakat, namun masih sering ditolak karena rasanya sedikit asam dan bau alkohol selama fermentasi. Karena apabila proses fermentasi berlangsung cukup lama maka dapat mengakibatkan tape memiliki rasa yang lebih asam dan bau alkohol yang sangat tajam. Oleh karena itu perlu dilakukan penelitian yaitu untuk mengetahui "Pengaruh lama proses fermentasi pada ubi kayu (Manihot esculenta Crantz) terhadap kadar asam lemak".

\section{METODE PENELITIAN}

\section{Jenis Penelitian}

Tipe penelitian yang digunakan adalah eksperimental murni (true eksperimental), menggunakan Rancangan Acak lengkap (RAL) dengan 5 perlakuan, 3 ulangan dan tiap ulangan terdiri dari 2 gram tape ubi kayu sesuai dengan petunjuk Hanafiah (2002). Perlakuan dalam penelitian ini adalah:

$\mathrm{P}_{0}$ : Tape ubi kayu tanpa fermentasi sebagai kontrol.

$\mathrm{P}_{1}$ : Tape ubi kayu difermentasikan selama 3 hari.

$\mathrm{P}_{2}$ : Tape ubi kayu difermentasikan selama 5 hari.

$\mathrm{P}_{3}$ : Tape ubi kayu difermentasikan selama 7 hari.

$\mathrm{P}_{4}$ : Tape ubi kayu difermentasikan selama 9 hari.

2. Variabel Penelitian

Variabel yang terdapat dalam penelitian ini yaitu: Variabel Bebas 
(Independent Variabel) yakni lama proses fermentasi pada ubi kayu. Variabel Terikat (Dependent Variabel) yakni kadar asam lemak pada ubi kayu

\section{Prosedur Penelitian}

a. Ubi kayu dikupas dan dibersihkan dengan air, selanjutnya dipotongpotong kecil atau dibiarkan utuh.

b. Ubi kayu dikukus sampai matang, kemudian dihamparkan di atas nyiru sampai dingin.

c. Ubi kayu yang telah dingin ditaburi dengan ragi sebanyak $0,5 \%$ - $1 \%$ dari berat ubi kayu yang digunakan.

d. Kemudian disimpan dan ditutup dengan daun atau plastik, bagian paling atas dari tumpukan ubi kayu ditaburi ragi lagi.

e. Setelah diperam selama 2-3 hari pada suhu kamar, tape sudah jadi.

f. Sampel diaduk merata dan berada dalam keadaan cair pada waktu diambil contohnya. g. Timbang sebanyak 28,2 gram \pm 0,2 gram contoh dalam erlenmeyer, kemudian tambahkan $50 \mathrm{ml}$ alkohol netral yang panas dan $2 \mathrm{ml}$ indikator $\mathrm{Pp}$ (Phenolphthalein).

h. Titrasilah dengan larutan $0,1 \mathrm{~N}$ $\mathrm{NaOH}$ yang telah distandarisasi sampai warna merah jambu tercapai dan tidak hilang selama 30 detik.

\section{Teknik Pengumpulan Data}

Data diperoleh dari penelitian ini terbagi menjadi 2 yaitu: Data primer yaitu data yang langsung diperoleh pada saat mengadakan penelitian dengan menggunakan tehnik analisis laboratorium untuk menentukan kadar asam lemak pada tape ubi kayu. Data sekunder yaitu data yang didapat dari hasil-hasil penelitian, literatur dan instansi terkait sesuai dengan permasalahan yang diteliti. Penentuan kadar Asam Lemak Bebas tape ubi kayu dengan rumus \% kadar Asam Lemak Bebas (FFA)

$\%$ Asam Lemak Bebas (FFA) $=\underline{m l ~ N a O H ~ x ~ N ~ x ~ 28,2 ~}$

berat contoh

Keterangan:

$\mathrm{Ml} \mathrm{NaOH}=$ Jumlah $\mathrm{NaOH}$ yang dipakai dalam titrasi

$\mathrm{N}=$ Normalitas $\mathrm{NaOH}$

28,2 = Sampel induk tetapan 
Berat contoh = Jumlah sampel yang dipakai dalam penelitian (Sudarmadji, 1984)

\section{Teknik Analisis Data}

Untuk mengetahui adanya pengaruh yang signifikan, dilakukan analisis data menggunakan Analisis Varians (ANAVA). Jika $\mathrm{F}_{\text {hitung }}>\mathrm{F}_{\text {tabel }}$ pada taraf signifikan 5\% dan $1 \%$ maka hipotesis $\mathrm{H}_{1}$ diterima dan hipotesis $\mathrm{H}_{0}$ ditolak. Sebaliknya jika $\mathrm{F}$ hitung $<\mathrm{F}$ tabel pada taraf signifikan $5 \%$ dan $1 \%$ maka hipotesis $\mathrm{H}_{0}$ diterima dan hipotesis $\mathrm{H}_{1}$ ditolak. Apabila pada analisis varians menunjukkan perbedaan nyata (siginifikan 5\%) maka dilanjutkan dengan Uji Beda Nyata Terkecil (BNT), untuk mengetahui derajat beda antar kelompok perlakuan. Steel dan Torrie, (dalam Sudjana, 1992).

HASIL PENELITIAN

Tabel 1 Perubahan Sifat Fisik Tape Ubi Kayu Selama Proses Fermentasi

\begin{tabular}{|c|c|c|}
\hline No. & $\begin{array}{l}\text { Hari/waktu } \\
\text { fermentasi }\end{array}$ & Spesifikasi \\
\hline 1. & $\begin{array}{l}\mathrm{P}_{0} \quad \text { (sebelum } \\
\text { difermentasikan) }\end{array}$ & $\begin{array}{l}\text { Warna tape putih atau kuning (tergantung } \\
\text { jenis ubi kayunya), tidak manis agak keras, } \\
\text { tidak berair, rasanya enak dan tidak berbau } \\
\text { alkohol. }\end{array}$ \\
\hline 2. & $\begin{array}{l}\mathrm{P}_{1} \text { (Fermentasi hari } \\
\text { ke 3) }\end{array}$ & $\begin{array}{l}\text { Warna putih kekuningan, rasa tape manis agak } \\
\text { berair, lunak, sedikit berbau alkohol, rasa tape } \\
\text { enak untuk dimakan. }\end{array}$ \\
\hline 3. & $\begin{array}{l}\mathrm{P}_{2}(\text { Fermentasi hari ke } \\
5)\end{array}$ & $\begin{array}{l}\text { Warna tape putih kekuningan, rasa tape manis, } \\
\text { dan sedikit asam, berair, lunak, rasa tape } \\
\text { kurang enak, dan bau alkohol sedikit tajam. }\end{array}$ \\
\hline 4. & $\begin{array}{l}\mathrm{P}_{3}(\text { Fermentasi hari ke } \\
7)\end{array}$ & $\begin{array}{l}\text { Warna tape putih kekuningan, rasa tape manis, } \\
\text { dan agak asam, berair, lunak, rasa tape tidak } \\
\text { enak, karena bau alkohol lebih tajam. }\end{array}$ \\
\hline 5. & $\begin{array}{l}\mathrm{P}_{4}(\text { Fermentasi hari ke } \\
9)\end{array}$ & $\begin{array}{l}\text { Warna tape putih kekuningan, rasanya asam } \\
\text { dan sedikit manis, sedikit pahit, berair, lunak, } \\
\text { bau alkohol sangat tajam, tape sangat tidak } \\
\text { enak untuk dimakan. }\end{array}$ \\
\hline
\end{tabular}

Tabel 2. Hasil Nilai Kandungan Kadar Asam Lemak Bebas (2 gram) Setelah Proses Titrasi Pelarut pada Tape Ubi Kayu

\begin{tabular}{|c|c|c|c|c|c|c|}
\hline \multirow[b]{2}{*}{ No. } & \multirow[b]{2}{*}{ Perlakuan } & \multicolumn{3}{|c|}{ Ulangan \% } & \multirow[b]{2}{*}{ Total } & \multirow[b]{2}{*}{ Rata-rata } \\
\hline & & I & II & III & & \\
\hline 1. & $\mathrm{P}_{0}$ & 0,42 & 0,42 & 0,38 & 1,22 & 0,40 \\
\hline 2. & $P_{1}$ & 3,47 & 3,19 & 3,16 & 9,82 & 3,27 \\
\hline 3. & $\mathrm{P}_{2}$ & 2,35 & 2,93 & 3,33 & 8,61 & 2,87 \\
\hline 4. & $\mathrm{P}_{3}$ & 2,02 & 1,76 & 1,86 & 5,64 & 1,88 \\
\hline \multirow[t]{2}{*}{5.} & $\mathrm{P}_{4}$ & 1,80 & 1,69 & 1,84 & 5,33 & 1,77 \\
\hline & Jumlah $(\Sigma)$ & 10,06 & 9,99 & 10,57 & 30,62 & 10,19 \\
\hline
\end{tabular}


Tabel 3. Hasil Analisis Kadar Asam Lemak Tape Ubi Kayu

\begin{tabular}{|l|l|l|l|l|l|l|}
\hline Sumber & Db & JK & KT & F hitung & \multicolumn{2}{|l|}{ F table } \\
& & & & & & \\
\cline { 3 - 7 } & & & & & & \\
& & & & & & \\
\hline Perlakuan & 4 & 14,9182 & 3,72955 & $66,6467 * *$ & 3,48 & 5,98 \\
Acak & 10 & 0,5596 & 0,05596 & & & \\
\hline Total & 14 & 15,4778 & & & & \\
\hline
\end{tabular}

Keterangan: $* *=$ Berpengaruh sangat nyata pada taraf signifikan $5 \%$ dan $1 \%$

Tabel 4. Uji Beda Nyata Terkecil (BNT) Antar Perlakuan Terhadap Kontrol

\begin{tabular}{|l|c|c|c|}
\hline Perlakuan & Rata-Rata & \multicolumn{2}{|c|}{ Notasi BNT } \\
\cline { 3 - 4 } & Perlakuan $(\%)$ & $\mathbf{5 \%}$ & $\mathbf{1 \%}$ \\
\hline Kontrol $\left(\mathrm{P}_{0}\right)$ & 0,40 & $\mathrm{a}$ & $\mathrm{a}$ \\
Hari ke 9 $\left(\mathrm{P}_{4}\right)$ & 1,77 & $\mathrm{a}$ & $\mathrm{a}$ \\
Hari ke 7 $\left(\mathrm{P}_{3}\right)$ & 1,88 & $\mathrm{a}$ & $\mathrm{a}$ \\
Hari ke 5 $\left(\mathrm{P}_{2}\right)$ & 2,87 & $\mathrm{a}$ & $\mathrm{a}$ \\
Hari ke 3 $\left(\mathrm{P}_{1}\right)$ & 3,27 & $\mathrm{~b}$ & $\mathrm{~b}$ \\
\hline
\end{tabular}

Keterangan: Angka-angka yang diikuti oleh huruf dan pada kolom yang sama berarti berbeda tidak sangat nyata $(1 \%)$.

\section{PEMBAHASAN}

Perubahan warna yang terjadi pada makanan disebabkan oleh faktor-faktor tertentu. Menurut Winarno dan Fardiaz (1982:14) enzim dapat menyebabkan perubahan cita rasa, warna dan tekstur dan sifat-sifat lain dari bahan pangan selain enzim warna pangan dari makanan dapat disebabkan oleh beberapa sumber dan salah satu yang terpenting disebabkan oleh pigmen yang ada dalam bahan nabati dan hewani. Menurut Muhyi (1992) bahwa rasa makanan merupakan faktor kedua yang menentukan cita rasa makanan setelah penampilan makanan yang disajikan merangsang saraf melalui indera

penglihatan

sehingga membangkitkan selera untuk mencicipi makanan itu sendiri. Sedangkan aroma yang disebarkan oleh makanan adalah daya tarik yang sangat kuat dan mampu merangsang indera pencium sehingga membangkitkan selera.

Berdasarkan hasil pengamatan, semakin lama proses fermentasi maka semakin tajam bau alkohol pada tape ubi kayu, dan rasa tape semakin asam, namun rasa manis dari tape itu sendiri masih ada. Pada fermentasi hari ke 3 bau alkohol tidak terasa dan tape rasanya enak, tetapi pada hari ke 5 rasa dan aroma tape mulai kurang enak karena bau alkohol sudah 
terasa dan sedikit asam. Dan pada fermentasi hari ke 7 dan ke 9, rasa tape tidak enak untuk dimakan, walaupun manis dari tape masih ada, rasa tidak enak disebabkan oleh alkohol yang tajam dan rasa asam yang ditimbulkan. Menurut Winarno, (1980), mengemukakan bahwa perubahan yang terjadi pada cita rasa bahan pangan biasanya lebih komplek dari pada yang terjadi pada warna bahan pangan. Cita rasa kopi, susu, daging, dan sebagian besar bahan pangan lainnya biasanya tidak stabil yaitu dapat mengalami perubahan selama penanganan, pengolahan dan penyimpanan.

Hasil Uji (BNT) pada tabel 4.3 di atas menunjukkan bahwa pada taraf uji $1 \%$ pengaruh lama fermentasi pada perlakuan 0 hari/ $\mathrm{P}_{0}$ (kontrol) dengan perlakuan hari ke $9\left(\mathrm{P}_{4}\right)$ berbeda tidak nyata pada taraf signifikan $1 \%$, perlakuan 0 hari/ $\mathrm{P}_{0}$ (kontrol) dengan perlakuan hari ke $7\left(\mathrm{P}_{3}\right)$ berbeda tidak nyata pada taraf signifikan $1 \%$, dan pada perlakuan 0 hari/ $\mathrm{P}_{0}$ (kontrol) dengan perlakuan hari ke 5 $\left(\mathrm{P}_{2}\right)$ berbeda tidak nyata pada taraf signifikan $1 \%$ sedangkan perlakuan 0 hari/ $\mathrm{P}_{0}$ (kontrol) dengan perlakuan hari ke 3
$\left(\mathrm{P}_{1}\right)$ berbeda nyata pada taraf signifikan $1 \%$.

Hasil ini sesuai dengan hasil titrasi tape ubi kayu seperti terlihat pada lampiran 3 yang menunjukkan bahwa kadar asam lemak pada waktu fermentasi 0 hari/ $\mathrm{P}_{0}$ (kontrol) adalah 1,22\%, dan pada waktu fermentasi hari ke 3 kadar asam lemak adalah 9,82\%, kadar asam lemak yang difermentasikan pada selang waktu 3 hari tersebut merupakan kadar asam lemak yang maksimum karena memiliki nilai yang paling tinggi dibandingkan dengan fermentasi hari ke 5, 7, dan ke 9. Hal ini diduga karena enzimenzim yang dihasilkan oleh kapang atau khamir selama proses fermentasi sudah mencapai titik optimum dengan baik untuk menghasilkan enzim-enzim tertentu seperti amilase, protease, lipase dan esterase yang dibutuhkan untuk katabolisme substrat sehingga mampu meningkatkan kadar asam lemak tape ubi kayu yang tinggi, dengan demikian kualitas hasil fermentasi tape ubi kayu akan semakin baik. Hal ini ditunjang pendapat Sardjoko (1992) mengatakan bahwa kapang atau khamir sebagai starter dalam proses fermentasi dalam keadaan aktif akan memproduksi berbagai enzim 
seperti amilase, protease, lipase maupun fitase sehingga akan membantu dalam meningkatkan kualitas pangan yang baik.

Pada waktu fermentasi hari ke 3 dengan kadar asam lemak 9,82\% ini pula diduga hubungan antara substrat dengan active site dari enzim terjadi. Hubungan atau kontak antara enzim dengan substrat tersebut menyebabkan terjadinya komplek enzim-substrat. Dengan terjadinya hubungan yang aktif tersebut enzim-enzim akan dihasilkan dan berfungsi dalam meningkatkan kadar asam lemak tape ubi kayu. Di samping pengaruh hubungan antara substrat dengan active site dari enzim di atas juga disebabkan oleh faktor fermentasi (peragian). Seperti yang dikemukakan oleh Norman Desrosier (1988) bahwa fermentasi merupakan suatu kegiatan penguraian bahan-bahan berkarbohidrat, sedangkan pembusukan berkenaan dengan kegiatan umum mikroba pada bahan-bahan yang berprotein. Pada proses fermentasi biasanya tidak menimbulkan bau busuk dan biasanya menghasilkan karbondioksida.

Kenaikan asam lemak ini juga disebabkan oleh enzim yang ada selama fermentasi. Menurut Winarno (1995:66), enzim-enzim yang bekerja dalam hidrolisis lemak dan minyak dikelompokkan menjadi 2 kelompok besar yaitu enzim lipase dan enzim esterase, keduanya terlihat baik dalam proses metabolisme lemak maupun penguraian dan kerusakan lemak. Berdasarkan nomenklatur dari International Union of Biochemistry, enzim lipase berfungsi mengkatalisis trigliserida menjadi

digliserida dan asam lemak.
Trigliserida $+\mathrm{H}_{2} \mathrm{O} \stackrel{\text { Enzim Lipase }}{\longrightarrow}$ Digliserida + asam lemak

Hal ini sesuai dengan pendapat S. (trigliserida) sehingga menghasilkan asam Ketaren (1986:63) yang mengemukakan lemak bebas dan gliserol, namun enzim bahwa lemak nabati yang masih berada tersebut inaktif oleh panas. Dengan dalam jaringan biasanya mengandung bertambahnya waktu fermentasi, kadar enzim dan dapat menghidrolisa lemak. asam lemak tape ubi kayu cenderung Semua enzim yang termasuk golongan menurun yaitu pada hari ke $5\left(\mathrm{P}_{3}\right)$ dengan lipase mampu menghidrolisa lemak netral kadar asam lemak 8,61\%. Hari ke 7 kadar 
asam lemaknya $5,64 \%$ dan untuk kayu. Selanjutnya pada keadaan ini pula fermentasi hari ke 9 kadar asam lemak enzim tidak dapat berfungsi terhadap bebas semakin menurun menjadi 5,33\%. substrat. Walaupun demikian konsentrasi Makin menurunnya kadar asam lemak enzim-enzim menunjukkan kecepatan bebas pada tape ubi kayu disebabkan oleh reaksi yang semakin meningkat. perubahan komposisi yang terjadi dalam Dimungkinkan juga pada kondisi tersebut pangan karena kecepatan respirasi dan active site dari enzim masih terdapat juga menurunnya keaktifan enzim lipase. Seperti yang dikemukakan oleh Winarno (1995:68) keaktifan optimum lipase sangat tergantung pada $\mathrm{pH}$ dan suhu optimal lipase pada umumnya berkisar antara $30^{\circ}$ dan $40^{\circ} \mathrm{C}$.

Perlakuan $\quad 0 \quad$ hari/ $\mathrm{P}_{0} \quad$ (kontrol) menunjukkan nilai kadar asam lemak terendah dan berbeda sangat nyata $(1 \%)$ dengan masing-masing perlakuan yang lain yaitu sebesar 1,22\%. Pada kadar asam lemak yang difermentasikan pada selang waktu 5 hari $\left(\mathrm{P}_{2}\right)$ tidak berbeda sangat nyata dengan selang waktu 7 hari $\left(\mathrm{P}_{3}\right)$ dan selang waktu 9 hari $\left(\mathrm{P}_{4}\right)$. Hal ini diduga pada selang waktu tersebut konsentrasi enzim-enzim yang dihasilkan oleh kapang atau khamir yang digunakan sebagai starter dalam proses fermentasi belum mencapai optimum untuk bereaksi dengan substrat dalam medium basal sehingga bagian yang longgar untuk menampung substrat sehingga dengan adanya bagian yang kosong tersebut akan berpengaruh pada konsentrasi enzim-enzim yang dihasilkan oleh kapang atau khamir dalam proses fermentasi. Dalam keadaan tersebut maka kadar asam lemak tape ubi kayu yang dipengaruhi oleh konsentrasi enzim yang dihasilkan kapang atau khamir dalam proses fermentasi belum optimal. Namun dengan selang waktu 5 hari $\left(\mathrm{P}_{2}\right)$ penggunaan kapang atau khamir tersebut sudah menunjukkan peningkatan nilai kadar asam lemak tape ubi kayu.

Seperti diketahui bahwa untuk dapat bekerja terhadap suatu zat atau substrat, harus ada kontak atau hubungan antara enzim dan substrat terlebih dahulu. Hal ini dikarenakan tidak seluruh bagian enzim dapat berhubungan dengan substrat. Hubungan antara substrat dengan enzim belum dapat secara maksimal hanya terjadi pada bagian atau tempat meningkatkan kadar asam lemak tape ubi tertentu yakni bagian aktif dari enzim itu 
(active site). Hal lain yang memungkinkan selang hari ke-5 $\left(\mathrm{P}_{2}\right)$ dengan kadar asam lemak $8,61 \%$ belum bisa optimal dalam menghasilkan enzim-enzim yang membantu proses fermentasi adalah pada tingkat selang hari tersebut diduga juga kecepatan reaksi dari enzim masih lambat dalam proses fermentasi. Seperti diketahui juga enzim adalah merupakan katalis yang sangat efisien dan mempunyai kekhasan tersendiri dalam reaksi kimia, sehingga dalam konsentrasi yang rendah kecepatan reaksi juga akan rendah. Hal ini ditunjang pendapat Poedjiadi (1994) bahwa kecepatan reaksi tergantung pada konsentrasi enzim dimana pada konsentrasi yang rendah kecepatan reaksi akan lambat dan pada konsentrasi yang tinggi kecepatan reaksi juga akan cepat. Pada selang hari ke-9 $\left(\mathrm{P}_{4}\right)$ dengan kadar asam lemak 5,33\% menunjukkan nilai kadar asam lemak tape ubi kayu yang menurun dan tidak menunjukkan perbedaan yang sangat nyata dengan perlakuan $\left(\mathrm{P}_{2}\right)$ dengan selang hari ke-5. Hal ini disebabkan bahwa hubungan yang komplek antara enzim dan substrat dari kapang atau khamir hanya aktif pada kondisi konsentrasi tertentu. Komplek yang aktif ini hanya bersifat sementara dan akan terurai lagi apabila reaksi yang diinginkan telah terjadi. Active site dari enzim apabila telah terpenuhi oleh substrat maka akan terjadi suatu titik kejenuhan dari enzim. Dan dengan kejenuhan dari enzim tersebut kecepatan reaksi akan menurun. Dengan menurunnya kecepatan reaksi tersebut maka konsentrasi enzim yang dihasilkan oleh kapang atau khamir dalam proses fermentasi tersebut juga akan menjadi kurang aktif.

\section{KESIMPULAN}

Berdasarkan hasil penelitian dan pembahasan serta pengujian statistika, maka dapat ditarik kesimpulan sebagai berikut: Terdapat perbedaan pengaruh Lama Proses Fermentasi pada ubi kayu (Manihot esculenta Crantz) terhadap kadar asam lemak untuk setiap perlakuan pada taraf kepercayaan $95 \%$ dan taraf kepercayaan 99\%. Waktu fermentasi yang memberikan kadar asam lemak bebas tertinggi adalah pada waktu fermentasi 3 hari yaitu $9,82 \%\left(\mathrm{P}_{1}\right)$.

\section{DAFTAR PUSTAKA}

Ansori Rahman. 1992. Teknologi Fermentasi. Arcan. Jakarta. 
Astawan Made. dan Astawan Mita Wahyuni. 1998. Teknologi Pengolahan Pangan Nabati Tepat Guna. Akademika Pressido. Jakarta.

Astawan, M., Deddy, M. dan Nurheri, P.S. 1993. Metabolisme Zat Gizi Sumber Fungsi dan Kebutuhan Bagi Tubuh Manusia. Jilid II, Pustaka Sinar Harapan. Jakarta.

Ansori, Rahman. 1992. Tekologi Fermentasi Industrial Cet II. Arcan. Jakarta.

Buckle, K.A.,dkk. 1987. Ilmu Pangan. UI Press. Jakarta.

Diane, M. Barret dan J. Wargiono. 1986. Budi Daya Ubi Kayu. PT. Gramedia. Jakarta.

Desrosier, Norman, W., 1988. Teknologi Pengawetan Pangan, IU Press: Jakarta.

Darwin, Karyadi, dan Muhlal. 1992. Kecukupan Gizi Yang Dianjurkan. PT. Gramedia. Jakarta.

E. Soebiyanto, Tjokro Adi Kusoemo. 1993. HFS dan Industri Ubi Kayu Lainny. PT. Gramedia, Pustaka Utama. Jakarta.

Edy, N. Seotanto. 2005. Membuat Keripik Ketela Rasa Gadung. Kanisius. Jakarta.

Gaman, P.M., dan Sherrington, K.B. 1984. Ilmu Pangan Pengantar Ilmu Pangan Nutrisi, dan Mikrobiologi. Gajah Mada University Press. Yogyakarta.

J. Wargiono, dan Diane, M. Barret. 1987. Budi Daya Ubi Kayu. Gramedia. Jakarta.

Ketaren, S., 1986. Pengantar Teknologi Minyak Dan Lemak Pangan. Universitas Indonesia. Jakarta.

Lingga, Pinus., dkk., 1989. Bertanam UbiUbian, Jakarta.
Moehyi, Syahmien. 1992. Makanan Institusi dan Jasa Boga. Bhratara. Jakarta.

Oey Kam Nio. 1992. Daftar Analisis Makanan. Fakultas Kedokteran Universitas Indonesia Cet I. Jakarta.

Poedjiadi, A. 1994. Dasar-Dasar Biokimia. Penerbit UI Press. Jakarta.

Rahmat Rukmana. 1997. Ubi Kayu Budi Daya dan Pascapanen. Kanisius: Yogyakarta.

1980. Ubi-Ubian. Lembaga biologi nasional. Balai Pustaka. Jakarta.

Sardjoko. 1992. Bioteknologi Latar Belakang dan Penerapannya. Penerbit Gramedia Pustaka Utama. Jakarta.

Slamet, Sudirmadji, Bambang Haryono, dan Suhardi. 1984. Prosedur Analisa Untuk Bahan Makanan Dan Pertanian, Liberty: Yogyakarta.

Sudigdo, F. Mulyokusumo. 1981. Tauco dan Tapai.Tarate. Bandung.

Soedjono. 1992. Seri Industri Pertanian Umbi-Umbian. Remaja Rosdakarya. Bandung.

Wirahadi, Kusuma, M., 1985. Biokimia; Metabolisme Energi, Karbohidrat, dan Lipid, ITB: Bandung.

Winarno, F.G. 1994. Sterilisasi Komersial Produk Pangan. Gramedia. Jakarta. 1995. Enzim Pangan, Gramedia Pustaka Utama: Jakarta.

Winarno, F.G., S. Fardiaz, dan D. Fardiaz. 1980. Pengantar Teknologi Pangan. Gramedia. Jakarta.

Winarno, F.G. dan Betty L.S. 1982. Kerusakan Bahan Pangan dan Cara Pencegahannya. Ghalia Indonesia. Jakarta. 